\title{
Prolonged food restriction and mild exercise in Shetland ponies: effects on weight gain, thyroid hormone concentrations and muscle $\mathrm{Na}^{+}, \mathrm{K}^{+}$-ATPase
}

\author{
P Suwannachot ${ }^{1}$, C B Verkleij ${ }^{1,3}$, S Kocsis ${ }^{1}$, E Enzerink ${ }^{2,4}$ \\ and $\mathbf{M}$ E Everts ${ }^{1}$ \\ ${ }^{1}$ Department of Anatomy and Physiology, Faculty of Veterinary Medicine, Utrecht University, PO Box 80.157, 3508 TD Utrecht, The Netherlands \\ ${ }^{2}$ Department of Equine Sciences, Faculty of Veterinary Medicine, Utrecht University, PO Box 80.157, 3508 TD Utrecht, The Netherlands \\ ${ }^{3}$ Academical Medical Center, Department of Endoscopy, Meibergdreef 9, 1105 AZ Amsterdam, The Netherlands \\ ${ }^{4}$ Veterinary Centre Someren, Slieven str. 16, 5711 PK Someren, The Netherlands \\ (Requests for offprints should be addressed to M E Everts, Department of Anatomy and Physiology, Faculty of Veterinary Medicine, Utrecht University, \\ PO Box 80·157, 3508 TD Utrecht, The Netherlands; Email: M.Everts@vet.uu.nl)
}

\begin{abstract}
We determined the effects of food supply and lowintensity training on growth, serum thyroid hormone levels and the $\mathrm{Na}^{+}, \mathrm{K}^{+}$-pump concentration in equine skeletal muscle. Twenty-two Shetland ponies were subjected to two different feeding regimes for $2 \frac{1}{2}$ years $(11$ ponies per group): food restriction (body condition score kept at 2) or ad libitum fed (body condition score kept at 8). Five ponies in each group underwent low-intensity training. Gluteus medius muscle and serum samples were obtained in April 1998. Subsequently, all ponies were fed ad libitum and the training programme was stopped. Muscle biopsies and serum samples were collected again in November 1998.

Food restriction was associated with a $30-50 \%$ reduction of body weight gain. While the total thyroxine $\left(\mathrm{T}_{4}\right)$ level was increased, the free $\mathrm{T}_{4}$ remained at the control level. The serum total tri-iodothyronine $\left(\mathrm{T}_{3}\right)$ and free $\mathrm{T}_{3}$ were
\end{abstract}

reduced by $30 \%$ and $49 \%$ respectively. After 6 months of refeeding there were no differences in any of the hormone levels between the ad libitum fed and the food-restricted groups. Food restriction produced a minor, but not significant, decrease in the $\mathrm{Na}^{+}, \mathrm{K}^{+}$-pump concentration in the gluteus medius muscle of the Shetland ponies. Lowintensity training reduced weight gain of the ad libitum fed group by $25 \%$, but had no detectable effect on the concentration of the $\mathrm{Na}^{+}, \mathrm{K}^{+}$-pumps.

We conclude that prolonged food restriction in Shetland ponies results in a weight gain reduction of $30-50 \%$, and is associated with similar decreases in serum total and free $T_{3}$. The reduction in serum $T_{3}$ only slightly influenced the $\mathrm{Na}^{+}, \mathrm{K}^{+}$-ATPase concentration in skeletal muscle, indicating that muscle tissue of different species may respond differently to changes in circulating thyroid hormones.

Journal of Endocrinology (2000) 167, 321-329

\section{Introduction}

Excitability of skeletal muscle is critically dependent on the concentration gradients of $\mathrm{Na}^{+}$and $\mathrm{K}^{+}$across the sarcolemma, which are regulated by the membrane-bound $\mathrm{Na}^{+}, \mathrm{K}^{+}$-pump (i.e. $\mathrm{Na}^{+}, \mathrm{K}^{+}$-ATPase) (for review see Nielsen \& Overgaard 1996). Regulation of the $\mathrm{Na}^{+}, \mathrm{K}^{+}-$ pump in skeletal muscle occurs by changes in either its activity (short-term) or its concentration (long-term). Long-term regulation of the concentration of $\mathrm{Na}^{+}, \mathrm{K}^{+}-$ ATPase is primarily exerted by thyroid hormones, which are the most potent stimulus for the synthesis of $\mathrm{Na}^{+}, \mathrm{K}^{+}$pumps (Clausen \& Everts 1989, Clausen 1998).

The effects of thyroid hormones on the concentration of $\mathrm{Na}^{+}, \mathrm{K}^{+}$-pumps in skeletal muscle have been reported in several studies both in rats and in humans (Kjeldsen et al.
1984, Brodie \& Sampson 1988, Everts et al. 1990). In addition, it has been shown that either partial or complete food restriction decreased the concentration of the $\mathrm{Na}^{+}, \mathrm{K}^{+}$-pumps in skeletal muscle due to the reduction of plasma thyroid hormone (tri-iodothyronine $\left(\mathrm{T}_{3}\right)$ and thyroxine $\left(\mathrm{T}_{4}\right)$ ) levels. Conversely, refeeding or $\mathrm{T}_{3}$ administration normalised the concentration of $\mathrm{Na}^{+}, \mathrm{K}^{+}$-pumps (Swann 1984, Kjeldsen et al. 1986a, Matsumura et al. 1992). In horses, food deprivation for 2 days has been shown to induce a significant reduction in serum thyroid hormone levels (Messer et al. 1995). On the other hand, Sticker et al. (1995) reported that dietary energy and/or protein restriction for 33 days did not alter circulating thyroid hormone levels in horses.

Apart from thyroid hormones, training was found to increase the skeletal muscle $\mathrm{Na}^{+}, \mathrm{K}^{+}$-pump concentration 
Table 1 Body condition score of individual animals in the four groups of Shetland ponies (April 1998)

\begin{tabular}{|c|c|c|c|c|}
\hline \multicolumn{5}{|c|}{ Treatment group } \\
\hline & $\mathrm{F}+/ \mathrm{T}-$ & $\mathrm{F}+/ \mathrm{T}+$ & $\mathrm{F}-/ \mathrm{T}-$ & $\mathrm{F}-/ \mathrm{T}+$ \\
\hline & 8 & 8 & 2 & 2 \\
\hline & 7 & 7 & 2 & 2 \\
\hline & 7 & 7 & 2 & 2 \\
\hline & 8 & 8 & 2 & 2 \\
\hline & 7 & 8 & 2 & 2 \\
\hline & 8 & - & 2 & - \\
\hline Mean \pm S.E. & $7 \cdot 5 \pm 0 \cdot 2$ & $7 \cdot 6 \pm 0 \cdot 2$ & $2 \cdot 0 \pm 0$ & $2 \cdot 0 \pm 0$ \\
\hline
\end{tabular}

For explanation of the symbols, see legend to Fig. 1.

both in man and in animals (Knochel et al. 1985, Kjeldsen et al. 1986b, Green et al. 1993, Madsen et al. 1994, McCutcheon et al. 1999, Suwannachot et al. 1999). In addition, hyperkalaemia during exercise was blunted in trained subjects (Knochel et al. 1985, Green et al. 1993, McKenna et al. 1993, McCutcheon et al. 1999), suggesting improved $\mathrm{K}^{+}$clearance during exercise.

The Shetland pony is a breed that is well-adapted for survival under the hard environmental conditions present on the Shetland Islands, i.e. low temperature, little and poor quality of food. However, nowadays, Shetland ponies are, in the vast majority of cases, raised as companion animals and under much more favourable climatic conditions; they are increasingly used in equine sport competitions. One of the nutritional problems of the Shetland pony is that under these circumstances they easily grow too fat, especially when they are fed a high-energy diet during growth. The question arises whether a low- or high- level of energy intake during growth influences the thyroid hormone levels and the $\mathrm{Na}^{+}, \mathrm{K}^{+}$-pump concentration, and thereby the contractile capacity of its muscles.

The objective of the present study was to explore how the factors referred to above (i.e. food supply combined with a low-intensity training programme) affect the growth, the thyroid hormone levels, and the concentration of $\mathrm{Na}^{+}, \mathrm{K}^{+}$-pumps in skeletal muscle of Shetland ponies.

\section{Materials and Methods}

\section{Animals}

Twenty-two Shetland ponies (six months old), 53 to $106 \mathrm{~kg}$ initial body weight (mean $81 \cdot 4 \pm 0 \cdot 2 \mathrm{~kg}$ ), were allotted (11 ponies per treatment) to one of two dietary treatments. Dietary treatments were formulated with the aim of total digestible energy meeting either 1000 VEP (restricted) or 2500 VEP (ad libitum fed) (VEP=Voeder Eenheid Paard=Feed Unit Horse), resulting in a low (2) and high (8) body condition score for restricted and ad libitum fed animals respectively (Table 1). Body condition score was estimated using the semi-quantitative method described by Henneke et al. (1983). In brief, the amount of stored fat in the body was estimated from the areas of the body where fat cover was visible and could be palpated. The areas selected as being indicative of changes in stored body fat were the lumbar spinous processes, ribs, tailhead, area behind the shoulder, neck and withers. Condition was evaluated on a scale of 1 to 9 , with 1 being extremely emaciated and 9 being extremely fat. Within each dietary treatment group, five ponies were subjected to a training regimen, which consisted of $40 \mathrm{~s}$ walk $(1.4 \mathrm{~m} / \mathrm{s}), 10 \mathrm{~s}$ trot $(3.3 \mathrm{~m} / \mathrm{s})$, and $15 \mathrm{~s}$ gallop $(6.1 \mathrm{~m} / \mathrm{s})$. The ponies were trained five days a week, and the exercising bout was alternated between 6 and 16 bouts a day every week. The ponies were kept separately in two groups of 11 animals (according to the feeding regimen) in large loose stalls $(13 \times 13 \mathrm{~m})$; therefore, they could move freely. From six months until one year of age, the ponies were fed three meals per day $(1 \times$ hay and $2 \times$ concentrates). After that they were fed twice daily $(1 \times$ hay and $1 \times$ concentrates $)$. Fresh water was available ad libitum. The experiment was started in August 1995. The first-time samples (muscle biopsy and serum) were obtained in April 1998, then the dietary treatment and exercise regimen were stopped. All ponies were fed ad libitum until November 1998, when the second-time samples were collected. The ponies were under intensive veterinary control. They received worm prophylaxis (dewormed) on a regular basis, and were checked by a veterinarian at least every seven weeks for general welfare and judgement of their exterior and the testicles. Between those periods the ponies were under the daily observation of experienced animal keepers. The experimental protocol has been approved by the Utrecht University Ethical Committee.

\section{Sampling procedure}

Blood samples were collected from the left jugular vein. Serum clot tubes were centrifuged; serum was harvested, frozen and stored at $-80{ }^{\circ} \mathrm{C}$ until analysed. The muscle samples were all taken from the left gluteus medius muscle percutaneously using the needle biopsy technique under local anaesthesia, according to the method described by Snow \& Guy (1976). To minimise variation in the $\mathrm{Na}^{+}, \mathrm{K}^{+}$-ATPase concentration due to the nonhomogeneous distribution of fibre types in skeletal muscle, all biopsies were taken by the same investigator, and the second biopsy was taken on the same side (left) within $2 \mathrm{~cm}$ of the first sample. The biopsy locations were identified using consistent anatomical landmarks and were at two-thirds of the distance along an imaginary line running from the tuber coxae to the tuber sacrale. Samples were taken in a direction perpendicular to the skin. The sampling depth varied from 4 to $6 \mathrm{~cm}$ (according to the muscle size and the body condition score). Samples were thus taken from the deep part of the dorsal compartment of 
the gluteus medius muscle (Valette et al. 1999). Biopsies (weighing around $70-100 \mathrm{mg}$ ) were immediately frozen in liquid nitrogen and stored at $-80{ }^{\circ} \mathrm{C}$ until analysed.

\section{$\left.{ }^{3} \mathrm{H}\right]$ Ouabain binding}

The $\mathrm{Na}^{+}, \mathrm{K}^{+}$-ATPase concentration was quantified by measuring $\left[{ }^{3} \mathrm{H}\right]$ ouabain binding capacity in the presence of vanadate $\left(\mathrm{VO}_{4}\right)$ as described by Nørgaard et al. (1983). This method allows the quantification of the total concentration of $\mathrm{Na}^{+}, \mathrm{K}^{+}$-ATPase in small samples of muscle. Furthermore, studies in rat and human skeletal muscle have shown that the values obtained correspond to the total population of functional $\mathrm{Na}^{+}, \mathrm{K}^{+}$-pumps (Clausen 1998). Since there was not enough tissue to make a complete standard curve with ouabain concentrations in the range $10^{-8} \mathrm{M}$ to $10^{-6} \mathrm{M}$, an ouabain concentration of $10^{-6} \mathrm{M}$ was used, since this has been shown to be above that required for saturation in rat (Nørgaard et al. 1983) and in foal (Suwannachot et al. 1999) muscle tissue. In brief, frozen biopsies were gently thawed and cut into small pieces weighing 5-10 $\mathrm{mg}$, and were incubated in baskets with the bottom attached to a gas inlet allowing continuous gassing with air to ensure agitation. The specimens were pre-washed twice for $10 \mathrm{~min}$ at $37^{\circ} \mathrm{C}$ in unlabelled buffer solution to remove any $\mathrm{Na}^{+}$and $\mathrm{K}^{+}$present, to avoid interference with the binding of ouabain and/or vanadate. The unlabelled buffer solution contained Tris $(24 \mathrm{mM}), \mathrm{MgSO}_{4}(3 \mathrm{mM})$, vanadate $(1 \mathrm{mM})$ and sucrose $(250 \mathrm{mM})$. The final $\mathrm{pH}$ was adjusted to $7 \cdot 3$ with $\mathrm{HCl}$. Incubation took place at $37{ }^{\circ} \mathrm{C}$ in buffer containing $0.6 \mu \mathrm{Ci} / \mathrm{ml}\left[{ }^{3} \mathrm{H}\right]$ ouabain and unlabelled ouabain added to a final concentration of $10^{-6} \mathrm{M}$ for $120 \mathrm{~min}$ under continuous gassing with air. One set of specimens was incubated at an ouabain concentration of $10^{-3} \mathrm{M}$ to allow correction for the unspecific uptake of $\left[{ }^{3} \mathrm{H}\right]$ ouabain. Incubation was followed by the washout of unbound $\left[{ }^{3} \mathrm{H}\right]$ ouabain, which took place in unlabelled buffer solution for $4 \times 30 \mathrm{~min}$ on ice. After the last washout period, the specimens were gently pressed between two pieces of filter paper. Each specimen was put into a counting vial and weighed. Then $0.5 \mathrm{ml} 5 \%$ trichloroacetic acid (TCA), containing $0.1 \mathrm{mM}$ ouabain, was added to each specimen. Finally, after $16 \mathrm{~h}$ extraction in the refrigerator, $3 \mathrm{ml}$ scintillation cocktail (Optifluor) were added and the ${ }^{3} \mathrm{H}$-activity was measured by liquid scintillation counting (Minaxi Tri-carb, 4000 series; Packard Bioscience B.V., Groningen, The Netherlands). On the basis of the specific activity of $\left[{ }^{3} \mathrm{H}\right]$ ouabain in the incubation medium, the amount of $\left[{ }^{3} \mathrm{H}\right]$ ouabain taken up and retained in the muscle samples was calculated and after correction (for unspecific uptake and isotopic purity) was expressed as $\mathrm{pmol} / \mathrm{g}$ wet weight.

\section{Serum thyroid hormones}

Serum 3,5,3'-tri-iodothyronine $\left(\mathrm{T}_{3}\right)$ and thyroxine $\left(\mathrm{T}_{4}\right)$ were measured using standard RIAs in unextracted serum.
Equilibrium dialysis was performed to estimate the serum $T_{3}$ and $T_{4}$ dialysable fractions. Free $T_{3}\left(F_{3}\right)$ and free $T_{4}$ $\left(\mathrm{FT}_{4}\right)$ were calculated as the product of either total $\mathrm{T}_{3}$ $\left(\mathrm{TT}_{3}\right)$ or total $\mathrm{T}_{4}\left(\mathrm{TT}_{4}\right)$ and their dialysable fractions (Sterling \& Brenner 1966).

\section{Serum $K^{+}$}

Serum $\mathrm{K}^{+}$was determined using air-acetylene flame atomic absorption spectrometry (Varian SpectrAA-250 plus; Varian Australia Pty. Ltd, Victoria, Australia). Serum samples were diluted to $1: 275$ in $5.5 \mathrm{ml}$ deionised water containing $0 \cdot 1 \%$ Cs to suppress partial ionisation in the air-acetylene flame. Calibration was performed with 6 standard solutions (containing the same amount of Cs as in the diluted samples) ranging from 0 to $0.038 \mathrm{mmol} / 1$ potassium.

\section{Chemicals}

All chemicals were of analytical grade. TCA and $\mathrm{K}^{+}$ standard (titrisol) were from Merck KGaA, Darmstadt, Germany. $\mathrm{CsCl}$, sucrose and $\mathrm{HCl}$ were from Mallinckrodt Baker, Inc., Phillipsburg, NJ, USA. Tris, $\mathrm{MgSO}_{4}$, ouabain, and vanadate were from Sigma Chemical Co., St Louis, MO, USA. Scintillation cocktail (Optifluor) was from Packard Bioscience B.V. $\left[{ }^{3} \mathrm{H}\right]$ Ouabain $(35 \cdot 0 \mathrm{Ci} /$ mmol) was from Amersham International, Amersham, Bucks, UK. According to the radiochemical batch analysis of Amersham, the 95\% purity of $\left[{ }^{3} \mathrm{H}\right]$ ouabain gave a correction factor of 1.05 for isotope impurity.

\section{Statistical analysis}

All data are given as mean values \pm S.E. The differences between the paired data were tested using the paired sample $t$-test. The differences among group means for the effects of food restriction, refeeding and training on the serum thyroid hormones, the $\left[{ }^{3} \mathrm{H}\right]$ ouabain binding sites, weight gain and serum $\mathrm{K}^{+}$in either April or November were subjected to ANOVA, and Levene's test was used to verify the homogeneity of variances. Multiple comparison (post-hoc test) was performed using the Tukey's honestly significant difference test or, when data had unequal variances, using the Games-Howell pairwise comparison test. The differences were considered to be significant if $P<0 \cdot 05$.

\section{Results}

\section{Weight gain}

At the start of the investigation (6 months of age), mean body weights of the four groups were not significantly 
Table 2 Body weights and weight gain of Shetland ponies. Values are means \pm S.E. The values in parentheses indicate the number of animals in each group

\begin{tabular}{|c|c|c|c|c|c|}
\hline & \multicolumn{3}{|c|}{ Body weight (kg) } & \multicolumn{2}{|c|}{ Weight gain (kg/day) } \\
\hline & Aug. 1995 & Apr. 1998 & Nov. 1998 & Aug. '95-Apr. '98 & Apr. '98-Nov. '98 \\
\hline \multicolumn{6}{|l|}{ Group } \\
\hline $\mathrm{F}+/ \mathrm{T}+(5)$ & $76 \cdot 2 \pm 5 \cdot 9$ & $169 \cdot 9 \pm 10 \cdot 2$ & $179 \cdot 6 \pm 12 \cdot 4$ & $0.095 \pm 0.006 \S$ & $0 \cdot 046 \pm 0 \cdot 014 \|$ \\
\hline $\mathrm{F}-/ \mathrm{T}-(6)$ & $81 \cdot 3 \pm 4 \cdot 4$ & $135 \cdot 3 \pm 13 \cdot 6$ & $172 \cdot 5 \pm 16 \cdot 7$ & $0.055 \pm 0.010$ & $0 \cdot 172 \pm 0 \cdot 016$ \\
\hline $\mathrm{F}-/ \mathrm{T}+(5)$ & $83 \cdot 6 \pm 7 \cdot 3$ & $148 \cdot 2 \pm 9 \cdot 7$ & $188 \cdot 4 \pm 12 \cdot 5$ & $0.066 \pm 0.004$ & $0 \cdot 186 \pm 0 \cdot 014$ \\
\hline
\end{tabular}

* $P<0.005 \mathrm{~F}+/ \mathrm{T}-\mathrm{vs} \mathrm{F}-/ \mathrm{T}-$ and $\mathrm{F}-/ \mathrm{T}+;+P<0.02 \mathrm{~F}+/ \mathrm{T}-\mathrm{vs} \mathrm{F}+/ \mathrm{T}+, \mathrm{F}-/ \mathrm{T}-$ and $\mathrm{F}-/ \mathrm{T}+; \neq P<0.001 \mathrm{~F}+/ \mathrm{T}-\mathrm{vs} \mathrm{F}-/ \mathrm{T}-$ and $\mathrm{F}-/ \mathrm{T}+; \S P<0.05 \mathrm{~F}+/ \mathrm{T}+\mathrm{vs}$ $\mathrm{F}-/ \mathrm{T}-$ and $\mathrm{F}-/ \mathrm{T}+; \| P<0 \cdot 001 \mathrm{~F}+/ \mathrm{T}+$ vs $\mathrm{F}-/ \mathrm{T}-$ and $\mathrm{F}-/ \mathrm{T}+$.

different, but a large variation among the individual animals existed. The mean body weights in April 1998 showed an even larger variation. As shown in Table 2, weight gain from August 1995 until April 1998 of the two ad libitum fed groups was significantly (30-50\%) higher than that of the two restricted diet groups $(P<0.05$ or better). This reflected the lower energy supply available for growth in the restricted groups. On the other hand, the growth rate from April until November 1998, which is the re-feeding and detraining period, of the restricted groups was significantly (3- to 10-fold) higher than that of the ad libitum fed groups $(P<0001$ for food restricted/untrained $(\mathrm{F}-/ \mathrm{T}-)$ and food restricted/trained $(\mathrm{F}-/ \mathrm{T}+)$ vs ad libitum fed/untrained $(\mathrm{F}+/ \mathrm{T}-)$ and ad libitum fed/trained $(\mathrm{F}+/ \mathrm{T}+)$ groups). Low-intensity training reduced the weight gain from August 1995 until April 1998 by 25\% $(P<0 \cdot 02)$ in the ad libitum fed group.

\section{Thyroid hormone status}

Results for serum concentrations of total $\mathrm{T}_{4}\left(\mathrm{TT}_{4}\right)$ and free $\mathrm{T}_{4}\left(\mathrm{FT}_{4}\right)$, and total $\mathrm{T}_{3}\left(\mathrm{TT}_{3}\right)$ and free $\mathrm{T}_{3}\left(\mathrm{FT}_{3}\right)$ are presented in Figs 1 and 2 respectively. It can be seen that food restriction increased serum $\mathrm{TT}_{4}$ by $40 \%$ compared with the ad libitum fed groups $(P<0 \cdot 01)$, while serum $\mathrm{FT}_{4}$ was the same in all groups (Fig. $1 \mathrm{~A}$ and $1 \mathrm{~B}$, solid bars). This was associated with a $30 \%$ and $49 \%$ reduction of serum $\mathrm{TT}_{3}$ and $\mathrm{FT}_{3} ; P<0 \cdot 05$ and $P<0 \cdot 01$ respectively
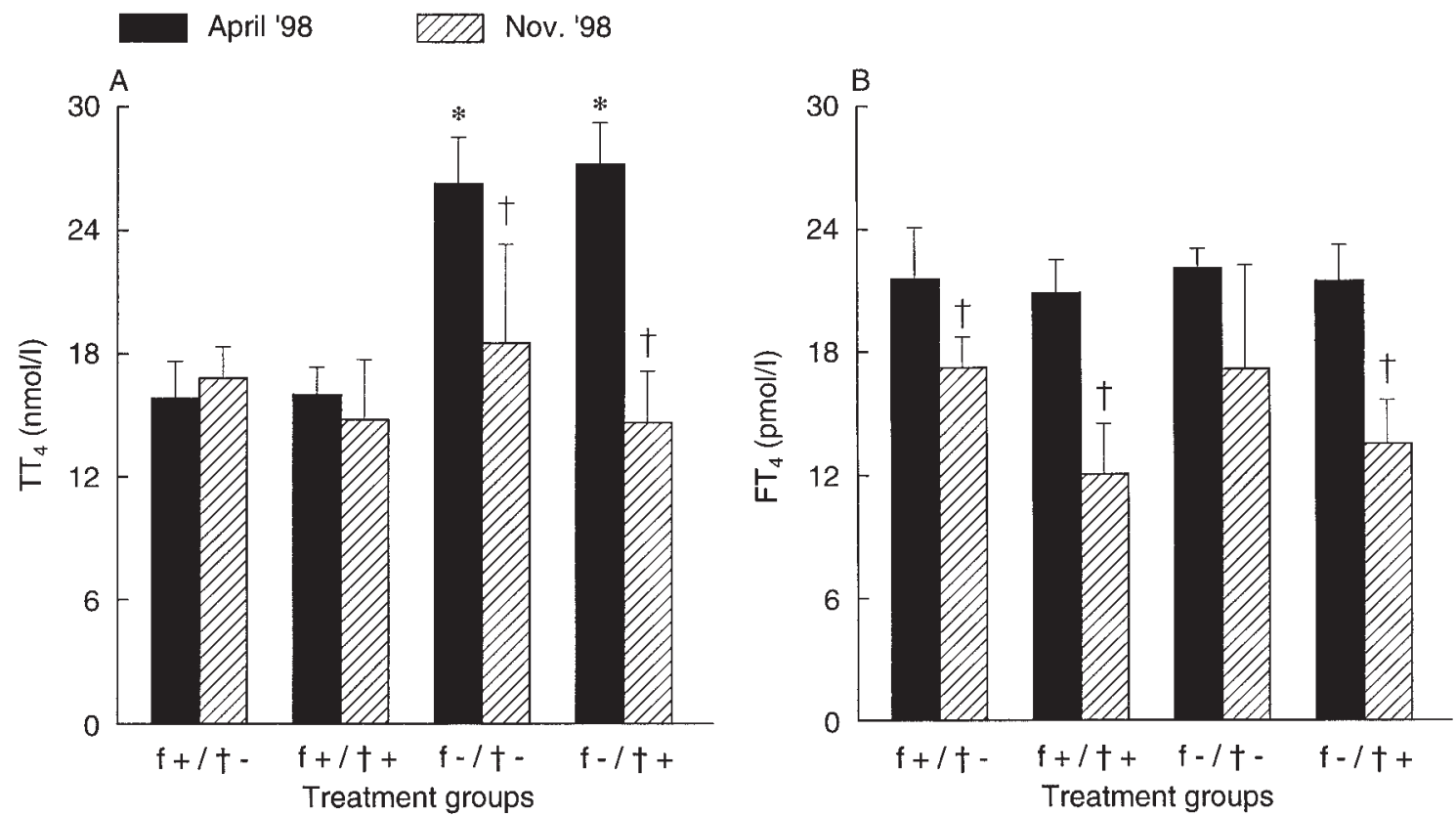

Figure 1 Serum thyroxine levels $\left(\mathrm{TT}_{4}: 1 \mathrm{~A}, \mathrm{FT}_{4}: 1 \mathrm{~B}\right)$ in the four groups of Shetland ponies $(\mathrm{f}+/ \mathrm{t}-$ : ad libitum fed/untrained, $\mathrm{f}+/ \mathrm{t}+$ : ad libitum fed/trained, $\mathrm{f}-/ \mathrm{t}-$ : restricted/untrained, $\mathrm{f}-/ \mathrm{t}+$ : restricted/trained) in April (solid bars) and in November (hatched bars). Each column shows the mean \pm S.E. of 5-6 ponies. * Indicates a significant $(P<0 \cdot 01)$ difference between food restriction and ad libitum fed. $†$ Indicates a significant $(P<0 \cdot 05)$ difference between April and November 1998. 

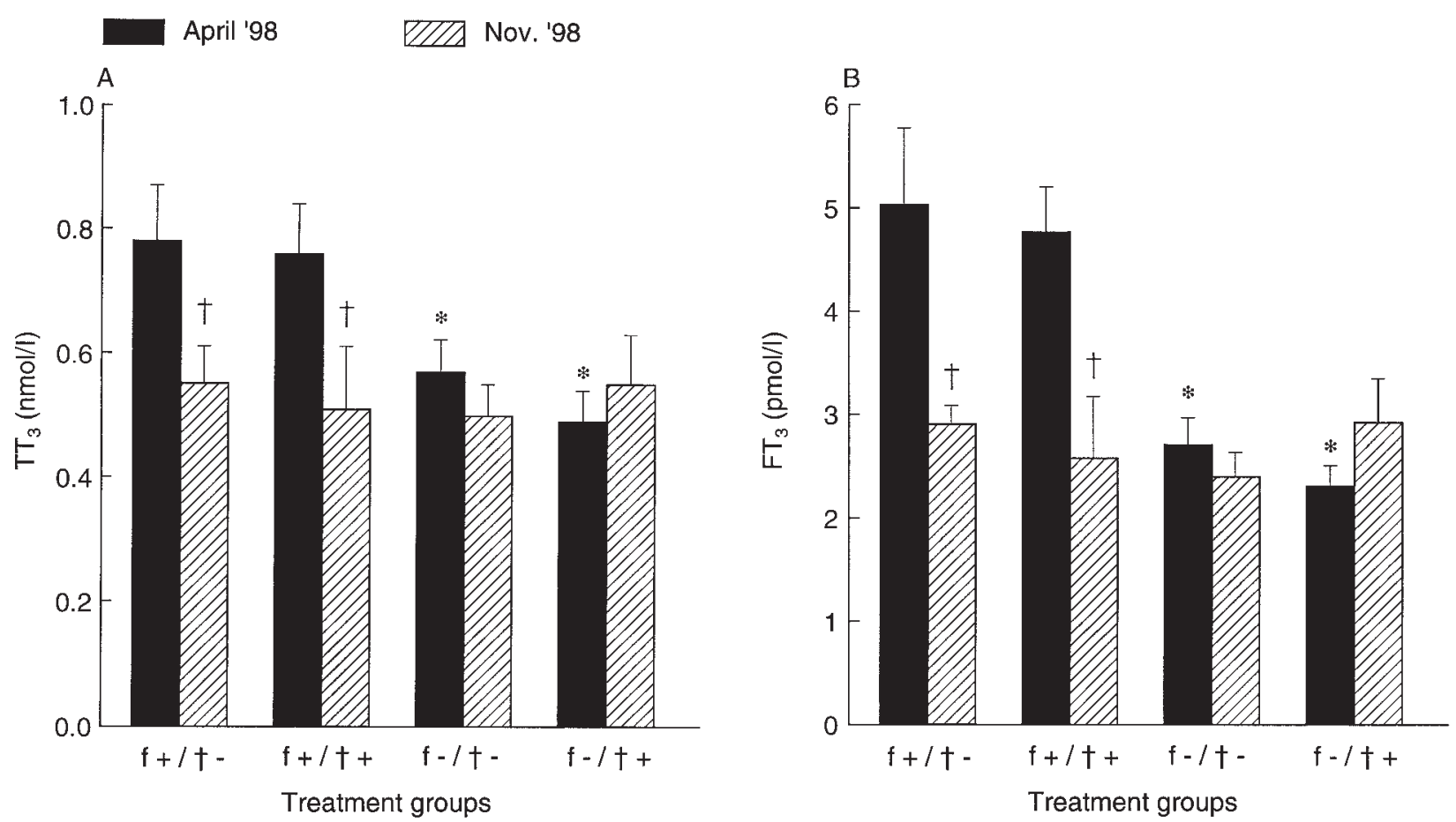

Figure 2 Serum 3,5,3'-tri-iodothyronine levels $\left(\mathrm{TT}_{3}: 2 \mathrm{~A}, \mathrm{FT}_{3}: 2 \mathrm{~B}\right)$ in the four groups of Shetland ponies. For explanation of the symbols, see legend to Fig. 1. Each column shows the mean \pm S.E. of 5-6 ponies. * Indicates a significant $(P<0 \cdot 05)$ difference between food restriction and ad libitum fed. † Indicates a significant $(P<0 \cdot 05)$ difference between April and November 1998.

(Fig. 2A and 2B, solid bars). Refeeding for 6 months normalised serum $\mathrm{TT}_{4}$ levels of the restricted groups to the baseline value (Fig. 1A, hatched bars). Surprisingly, serum $\mathrm{TT}_{3}$ and $\mathrm{FT}_{3}$ of the restricted groups did not increase after the period of refeeding, but serum $\mathrm{TT}_{3}$ and $\mathrm{FT}_{3}$ levels in the ad libitum fed groups were decreased to the same level as in the restricted groups (Fig. 2A and 2B, hatched bars). There was no difference in serum $\mathrm{TT}_{3}$ and $\mathrm{FT}_{3}$ levels between the period of food restriction and refeeding in the restricted groups (Fig. 2A and 2B, hatched bars). Serum $\mathrm{FT}_{4}$ in all four groups was decreased in November compared with the values in April (Fig. 1B, hatched bars). No effects of training or detraining were found on the thyroid hormone levels in the restricted and the ad libitum fed groups.

\section{$\left.{ }^{3} \mathrm{H}\right]$ Ouabain binding site concentration}

The concentration of $\mathrm{Na}^{+}, \mathrm{K}^{+}$-ATPase expressed per gram wet weight in gluteus medius muscle is presented in Fig. 3. Neither food intake nor training induced any significant change in the $\mathrm{Na}^{+}, \mathrm{K}^{+}$-ATPase concentration between groups during the food restriction or the refeeding period. However, during the food restriction period, the mean values of the $\mathrm{Na}^{+}, \mathrm{K}^{+}$-ATPase concentration in the ad libitum fed groups were $12-15 \%$ higher than those of the restricted groups. After 6 months of refeeding, the mean values of the $\mathrm{Na}^{+}, \mathrm{K}^{+}$-ATPase concentration of the restricted groups showed a slight increase (6-16\%) compared with the food restriction period. Conversely, the mean values of the $\mathrm{Na}^{+}, \mathrm{K}^{+}$-ATPase concentration of the ad libitum fed groups were slightly decreased by $12-15 \%$.

\section{Serum $K^{+}$}

Results of the serum $\mathrm{K}^{+}$concentration are presented in Fig. 4. Neither food restriction nor training resulted in any significant change in serum $\mathrm{K}^{+}$among the groups in April. The serum $\mathrm{K}^{+}$in the restricted/untrained group was significantly increased after the 6-month refeeding period $(P<0 \cdot 05)$.

\section{Discussion}

Undernutrition and/or starvation including caloric restriction are accompanied by a reduction in thyroid hormone levels, which subsequently may lead to a reduction in the $\mathrm{Na}^{+}, \mathrm{K}^{+}$-ATPase concentration in skeletal muscle as shown for rats and pigs (Swann 1984, Kjeldsen et al. 1986a, Dauncey \& Burton 1989, Matsumura et al. 1992, Harrison et al. 1996). Skeletal muscle contains the largest pool of $\mathrm{Na}^{+}, \mathrm{K}^{+}$-ATPase in the body, representing a considerable capacity for the clearance of $\mathrm{K}^{+}$from the 
April '98

एZ7] Nov. '98

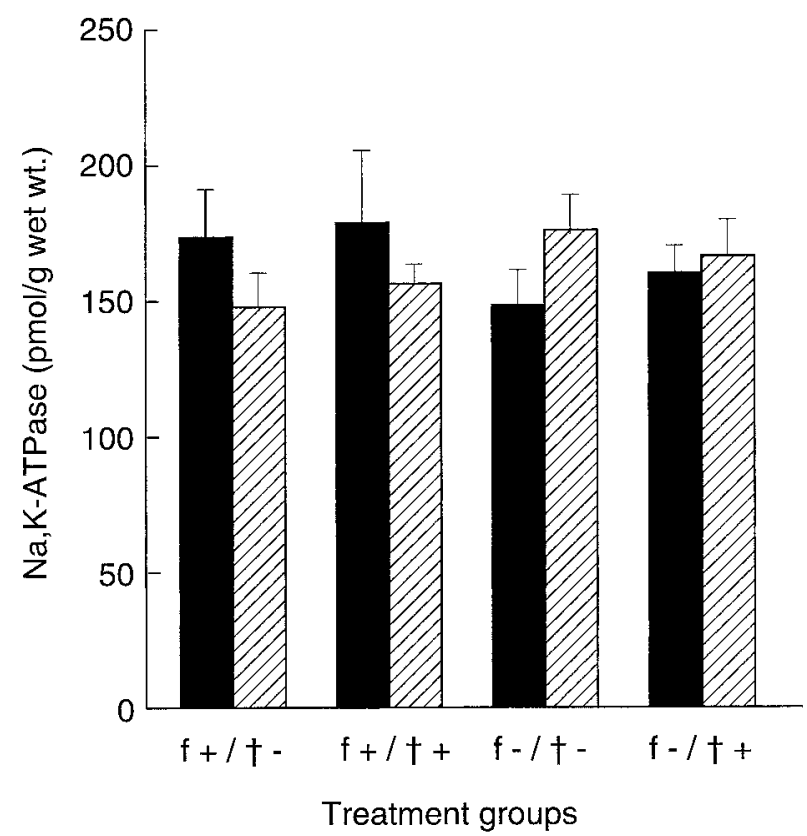

Figure 3 Effects of food restriction, low-intensity training and refeeding on the concentration of $\mathrm{Na}^{+}, \mathrm{K}^{+}$-ATPase in gluteus medius muscle of Shetland ponies. For explanation of the symbols, see legend to Fig. 1. Each column shows the mean \pm S.E. of 5-6 ponies in each group. There were no significant differences between groups or months.

plasma, for restoration of the membrane potential and maintenance of contractile performance (Clausen \& Everts 1989, Nielsen \& Overgaard 1996). Since the equine species is considered to be a great athletic species, restricted energy intake, especially during growth, may affect the $\mathrm{Na}^{+}, \mathrm{K}^{+}$-ATPase concentration due to changes in thyroid hormone levels as well as the development of the muscle, and thus diminish potential athletic performance.

At variance with other reports in horses showing that neither plasma $T_{3}$ nor $T_{4}$ concentrations were altered due to restriction of the food supply (Glade et al. 1984, Glade \& Reimers 1985, Sticker et al. 1995), the present results show that prolonged dietary caloric restriction in Shetland ponies is not unexpectedly associated with a diminished body weight gain, but is also accompanied by changes in thyroid hormone metabolism. As a consequence of dietary energy restriction, serum $\mathrm{TT}_{4}$ increased (40\%) while serum $\mathrm{TT}_{3}$ and $\mathrm{FT}_{3}$ decreased $(30 \%$ and $49 \%)$. This difference may be due to variation in the severity and the period of food restriction. In our study food restriction was rather severe, resulting in a body condition score of 2 on a scale ranging from 1 (extremely emaciated) to 9 (extremely fat). Yambayamba et al. (1996) found that the $\mathrm{TT}_{3}$ and $\mathrm{TT}_{4}$ concentration of food restricted heifers did not

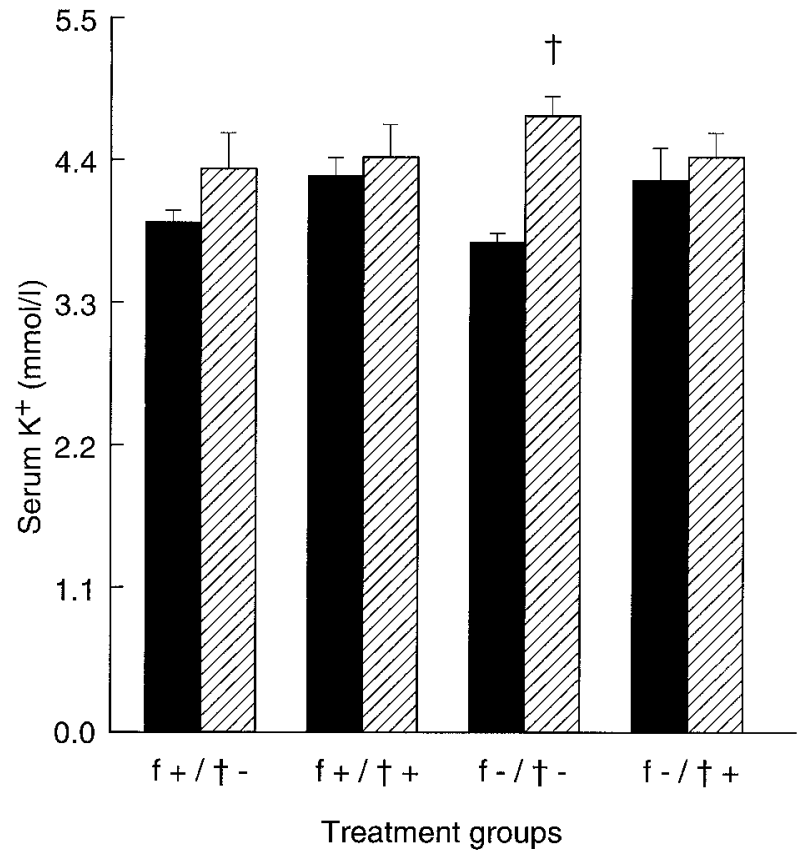

Figure 4 Histogram showing the concentration of serum $\mathrm{K}^{+}$for the four groups of Shetland ponies as described in the legend to Fig. 1. $†$ Indicates a significant $(P<0 \cdot 05)$ difference between April and November.

differ from those of ad libitum fed heifers on day 20, but a difference existed after 48 days. Thus food restriction to $50-80 \%$ of the daily requirement (Glade et al. 1984, Glade \& Reimers 1985, Sticker et al. 1995) for $\leq 1$ month may not be long enough for horses to adapt their metabolic hormonal regulation. However, short-term food restriction in horses may influence cellular metabolism since caloricrestricted horses showed reduced levels of plasma glucose and insulin, and increased plasma nonesterified fatty acid concentrations (Sticker et al. 1996). The changes in thyroid hormone levels in the present study, with elevated $\mathrm{TT}_{4}$ and decreased $\mathrm{TT}_{3}$ and $\mathrm{FT}_{3}$ are similar to those seen in caloric-restricted cats (Fettman et al. 1998) as well as in humans suffering from malnutrition (Wartofsky \& Burman 1982). This may represent an adaptive response to minimise the basal metabolic rate during conditions of a negative caloric balance. The low $\mathrm{T}_{3}$ may be the result of either reduced $T_{4}$ to $T_{3}$ conversion (Aláez et al. 1992) or reduced transport of $\mathrm{T}_{4}$ into the liver (Hennemann et al. 1998). The finding of an increased serum $\mathrm{TT}_{4}$ with normal $\mathrm{FT}_{4}$ values in the ponies fed a restricted diet suggests that most of the rise in serum $\mathrm{TT}_{4}$ is accounted for by elevation of the protein-bound hormone.

The changes in the thyroid hormone levels we observed following the refeeding period are not easy to explain. 
Although serum $\mathrm{TT}_{4}$ in the restricted groups was normalised, serum $\mathrm{TT}_{3}$ and $\mathrm{FT}_{3}$ remained the same as in the restriction period. It could be that not only food intake but also environmental factors, such as temperature and/or seasonal variation, influenced the thyroid hormone levels during this period. This is supported by the fall in serum $\mathrm{TT}_{3}$, and $\mathrm{FT}_{3}$ in the ad libitum fed groups. In addition, the $\mathrm{FT}_{4}$ level which did not differ between the groups during the restriction period (April), tended to decrease in November. Seasonal variation in thyroid hormone levels has been reported in several mammalian species including horses, and this variation is thought to be dependent on environmental temperature and/or photoperiod (Johnson 1986, Clariget et al. 1998, Rhind et al. 1998). However, it should be noted that a difference in species and/or geographic locations (latitudes of $40^{\circ} 30^{\prime} \mathrm{N}$, Johnson 1986; $57^{\circ} \mathrm{N}$, Rhind et al. 1998 ; and $52^{\circ} \mathrm{N}$, the present results), causing a difference in temperature and daylight period, may influence the month of hormone peak throughout the year.

Interestingly, food restriction was associated with a reduced body weight gain and reduced total and free $T_{3}$ levels, while refeeding was accompanied by a 3 - to 10 -fold higher growth rate without a rise in total and free $T_{3}$. Apart from the seasonal variation in thyroid hormone levels as mentioned above, this could also suggest that growth hormone and/or insulin-like growth factor-I (IGF-I) are more important for the catch-up growth in the refeeding period (Everts et al. 1990). Glucocorticoids may also play a role in body weight gain during the food restriction period as well as during the refeeding period (Sticker et al. 1995) since they are involved in gluconeogenesis, lypolysis and protein catabolism (Irvine 1983). Unfortunately, we had insufficient serum to determine growth hormone, IGF-I and glucocorticoids.

Unlike studies in rats (Swann 1984, Kjeldsen et al. 1986a), the $\mathrm{Na}^{+}, \mathrm{K}^{+}$-ATPase concentration in gluteus medius of the ponies did not show any significant change due to the low serum $T_{3}$ mediated by food restriction. However, it should be noted that the fall in serum $\mathrm{T}_{3}$ during the restriction period did not reach a level lower than that found in ad libitum fed animals in November, which is presumed to be due to seasonal variation. Furthermore, the reduced body weight gain associated with food restriction will also reflect changes in the muscle, such as a relatively smaller fibre size or cross sectional area (Harrison et al. 1994), and thereby a greater plasma membrane surface area per unit wet weight. Since the $\mathrm{Na}^{+}, \mathrm{K}^{+}$-ATPase concentration in the present study is expressed per unit wet weight, the reduction in $\mathrm{Na}^{+}, \mathrm{K}^{+}$ATPase concentration would have been greater if the change in plasma membrane area could be taken into account. As can be seen from the results, food restriction induced a decrease in $\mathrm{TT}_{3}$ and $\mathrm{FT}_{3}$, and subsequently decreased the $\mathrm{Na}^{+}, \mathrm{K}^{+}$-ATPase concentration by around 12-15\%. Refeeding did not alter serum $\mathrm{TT}_{3}$ and $\mathrm{FT}_{3}$ levels in the restricted diet ponies, which is probably due to seasonal variation as mentioned before, but it did result in an increase of between 6 and $16 \%$ in $\mathrm{Na}^{+}, \mathrm{K}^{+}$-ATPase concentration. In addition, the fall in $\mathrm{TT}_{3}$ and $\mathrm{FT}_{3}$ in the ad libitum fed groups in November was accompanied by a reduction of $12-15 \%$ in $\mathrm{Na}^{+}, \mathrm{K}^{+}$-ATPase concentration. This suggests that thyroid status may have some influence on the $\mathrm{Na}^{+}, \mathrm{K}^{+}$-ATPase concentration in Shetland ponies, but the effect of mild hypothyroidism (low $\mathrm{T}_{3}$ ) is smaller than that seen in rats. This may be due to speciesdependent differences in the response of skeletal muscle tissue to thyroid hormones such as $\mathrm{Na}^{+}, \mathrm{K}^{+}$-ATPase isoform expression (Sweadner 1989, Azuma et al. 1993) and/or the number of $\mathrm{T}_{3}$ receptors (Morovat \& Dauncey 1995, Harrison et al. 1996).

Since the training intensity in the present study was rather low, we could not observe a significant rise in $\mathrm{Na}^{+}, \mathrm{K}^{+}$-ATPase concentration. This suggests that there is a certain threshold for up-regulation of the $\mathrm{Na}^{+}, \mathrm{K}^{+}-$ ATPase concentration, and also supports a conclusion from our previous study that the increase in $\mathrm{Na}^{+}, \mathrm{K}^{+}$-ATPase concentration following training seems to be related to the amount and intensity of exercise (Suwannachot et al. 1999). $\mathrm{K}^{+}$deficiency has been shown to down-regulate $\mathrm{Na}^{+}, \mathrm{K}^{+}$-ATPase concentration in rat skeletal muscle (Kjeldsen et al. 1986a, Clausen \& Everts 1989). The present results show that food restriction did not influence the serum $\mathrm{K}^{+}$concentration of the ponies. Although the serum $\mathrm{K}^{+}$in the restricted/untrained group was significantly increased after the 6-month refeeding period, it is unlikely that food restriction leads to $\mathrm{K}^{+}$deficiency since serum $\mathrm{K}^{+}$of the restricted/trained group showed no significant difference between the restricted and the refeeding period.

In conclusion the present results suggest that food restriction in Shetland ponies induces a large decrease in body weight gain, and is associated with a decrease in serum total and free $T_{3}$. The reduction in circulating $T_{3}$ may interfere with growth, development and metabolism of muscle cells. The changes in serum $\mathrm{T}_{3}$ concentration due to food restriction only slightly influenced the skeletal muscle $\mathrm{Na}^{+}, \mathrm{K}^{+}$-ATPase concentration. This indicates that skeletal muscle of different species may respond differently to changes in circulating thyroid hormones. For further understanding of the influence of thyroid hormones on the $\mathrm{Na}^{+}, \mathrm{K}^{+}$-ATPase concentration in horses, the $\mathrm{Na}^{+}, \mathrm{K}^{+}-$ ATPase isoform expression and the number of $\mathrm{T}_{3}$ receptors in skeletal muscle should be the focus of future investigations.

\section{Acknowledgements}

The authors would like to thank the Institute of Horse Husbandry, Lelystad (The Netherlands) for taking care of the animals and collecting the data on food supply and 
body weight. Mr H van Toor of the Department of Internal Medicine III, Erasmus University, Rotterdam (The Netherlands) is gratefully acknowledged for the thyroid hormone determinations. Dr P R van Weeren is acknowledged for critical reading and comments on the manuscript. Pisit Suwannachot holds a grant from the Ministry of University Affairs and the Civil Service Commission of the Royal Thai Government for the PhD training programme.

\section{References}

Aláez C, Calvo R, Obregón MJ \& Pascual-Leone AM 1992 Thyroid hormones and $5^{\prime}$-deiodinase activity in neonatal undernourished rats. Endocrinology $130773-779$.

Azuma KK, Hensley CB, Tang M-J \& McDonough AA 1993 Thyroid hormone specifically regulates skeletal muscle $\mathrm{Na}^{+}-\mathrm{K}^{+}-$ ATPase $\alpha_{2}$ and $\beta_{2}$-isoforms. American Journal of Physiology 265 C680-C687.

Brodie C \& Sampson SR 1988 Characterization of thyroid hormone effects on $\mathrm{Na}-\mathrm{K}$ pump and membrane potential of cultured rat skeletal myotubes. Endocrinology 123 891-897.

Clariget RP, Forsberg M \& Rodrigues-Martinez H 1998 Seasonal variation in live weight, testes size, testosterone, LH secretion, melatonin and thyroxine in Merino and Corriedale rams in a subtropical climate. Acta Veterinaria Scandinavica 39 35-47.

Clausen T 1998 Clinical and therapeutic significance of the $\mathrm{Na}^{+}, \mathrm{K}^{+}$ pump. Clinical Science 95 3-17.

Clausen T \& Everts ME 1989 Regulation of the Na,K-pump in skeletal muscle. Kidney International 35 1-13.

Dauncey MJ \& Burton KA $1989{ }^{3} \mathrm{H}$-Ouabain binding sites in porcine skeletal muscle as influenced by environmental temperature and energy intake. Pflügers Archiv 414 317-323.

Everts ME, Dørup I, Flyvbjerg A, Marshall SM \& Jørgensen KD 1990 $\mathrm{Na}^{+}-\mathrm{K}^{+}$pump in rat muscle: effects of hypophysectomy, growth hormone, and thyroid hormone. American Journal of Physiology 259 E278-E283.

Fettman MJ, Stanton CA, Banks LL, Johnson DE, Hamar DW, Hegstad RL \& Johnston 1998 Effects of weight gain and loss on metabolic rate, glucose tolerance, and serum lipid in domestic cats. Research in Veterinary Science 64 11-16.

Glade MJ \& Reimers TJ 1985 Effects of dietary energy supply on serum thyroxine, triiodothyronine and insulin concentrations in young horses. Journal of Endocrinology 104 93-98.

Glade MJ, Gupta S \& Reimers TJ 1984 Hormonal responses to high and low planes of nutrition in weanling Thoroughbreds. Journal of Animal Science 59 658-665.

Green HJ, Chin ER, Ball-Burnett M \& Ranney D 1993 Increases in human skeletal muscle $\mathrm{Na}^{+}-\mathrm{K}^{+}$-ATPase concentration with shortterm training. American Journal of Physiology 264 C1538-C1541.

Harrison AP, Clausen T, Duchamp C \& Dauncey MJ 1994 Roles of skeletal muscle morphology and activity in determining $\mathrm{Na}^{+}-\mathrm{K}^{+}-$ ATPase concentration in young pigs. American Journal of Physiology 266 R102-R111.

Harrison AP, Tivey DR, Clausen T, Duchamp C \& Dauncey MJ 1996 Role of thyroid hormones in early postnatal development of skeletal muscle and its implications for undernutrition. British Journal of Nutrition 76 841-855.

Henneke DR, Potter GD, Kreider JL \& Yeates BF 1983 Relationship between condition score, physical measurements and body fat percentage in mares. Equine Veterinary Journal 15 371-372.

Hennemann G, Everts ME, de Jong M, Lim C-F, Krenning EP \& Docter R 1998 The significance of plasma membrane transport in the bioavailability of thyroid hormone. Clinical Endocrinology 48 1-8.
Irvine CHG 1983 The role of hormones in exercise physiology. In Equine Exercise Physiology, pp 377-388. Eds DH Snow, SGB Persson \& RJ Rose. Cambridge, UK: Granta Editions.

Johnson AL 1986 Serum concentrations of prolactin, thyroxine and triiodothyronine relative to season and the estrous cycle in the mare. Journal of Animal Science 62 1012-1020.

Kjeldsen K, Nørgaard A, Gøtzsche CO, Thomassen A \& Clausen T 1984 Effect of thyroid function on number of Na-K pumps in human skeletal muscle. Lancet 2 8-10.

Kjeldsen K, Everts ME \& Clausen T 1986a Effects of semi-starvation and potassium deficiency on the concentration of $\left[{ }^{3} \mathrm{H}\right]$ ouabainbinding sites and sodium and potassium contents in rat skeletal muscle. British Journal of Nutrition 56 519-532.

Kjeldsen K, Richter EA, Galbo H, Lortie G \& Clausen T 19866 Training increases the concentration of $\left[{ }^{3} \mathrm{H}\right]$ ouabain-binding sites in rat skeletal muscle. Biochimica et Biophysica Acta 860 708-712.

Knochel JP, Blachley JD, Johnson JH \& Carter NW 1985 Muscle cell electrical hyperpolarization and reduced exercise hyperkalemia in physically conditioned dogs. Journal of Clinical Investigation $\mathbf{7 5}$ 740-745.

McCutcheon LJ, Geor RJ \& Shen H 1999 Skeletal muscle $\mathrm{Na}^{+}, \mathrm{K}^{+}-$ ATPase and $\mathrm{K}^{+}$homeostasis during exercise: effects of short-term training. Equine Veterinary Journal Supplement 30 303-310.

McKenna MJ, Schmidt TA, Hargreaves M, Cameron L, Skinner SL \& Kjeldsen K 1993 Sprint training increases human skeletal muscle $\mathrm{Na}^{+}-\mathrm{K}^{+}$-ATPase concentration and improves $\mathrm{K}^{+}$regulation. Journal of Applied Physiology 75 173-180.

Madsen K, Franch J \& Clausen T 1994 Effects of intensified endurance training on the concentration of $\mathrm{Na}, \mathrm{K}$-ATPase and Ca-ATPase in human skeletal muscle. Acta Physiologica Scandinavica 150 251-258.

Matsumura M, Kuzuya N, Kawakami Y \& Yamashita K 1992 Effects of fasting, refeeding, and fasting with $\mathrm{T}_{3}$ administration on $\mathrm{Na}, \mathrm{K}-\mathrm{ATP}$ ase in rat skeletal muscle. Metabolism 41 995-999.

Messer NT, Johnson PJ, Refsal KR, Nachreiner RF, Ganjam VK \& Krause GF 1995 Effect of food deprivation on baseline iodothyronine and cortisol concentrations in healthy, adult horses. American Journal of Veterinary Research 56 116-121.

Morovat A \& Dauncey MJ 1995 Regulation of porcine skeletal muscle nuclear 3,5,3'-tri-iodothyronine receptor binding capacity by thyroid hormones: modification by energy balance. Journal of Endocrinology 144 233-242.

Nielsen OB \& Overgaard K 1996 Ion gradients and contractility in skeletal muscle: the role of active $\mathrm{Na}^{+}, \mathrm{K}^{+}$transport. Acta Physiologica Scandinavica 156 247-256.

Nørgaard A, Kjeldsen K, Hansen O \& Clausen T 1983 A simple and rapid method for the determination of the number of ${ }^{3} \mathrm{H}$-ouabain binding sites in biopsies of skeletal muscle. Biochemical and Biophysical Research Communications 111 319-325.

Rhind SM, McMillen SR, Duff E, Hirst D \& Wright S 1998 Seasonality of meal patterns and hormonal correlates in red deer. Physiology and Behavior 65 295-302.

Snow DH \& Guy PS 1976 Percutaneous needle muscle biopsy in the horse. Equine Veterinary Journal 8 150-155.

Sterling K \& Brenner 1966 Free thyroxine in human serum: simplified measurement with the aid of magnesium precipitation. Journal of Clinical Investigation 45 153-163.

Sticker LS, Thompson Jr DL, Fernandez JM, Bunting LD \& DePew CL 1995 Dietary protein and(or) energy restriction in mares: plasma growth hormone, IGF-I, prolactin, cortisol, and thyroid hormone responses to feeding, glucose, and epinephrine. Journal of Animal Science 73 1424-1432.

Sticker LS, Thompson Jr DL , Bunting LD \& Fernandez JM 1996 Dietary protein and energy restriction in mares: rapid changes in plasma metabolite and hormone concentrations during dietary alteration. Journal of Animal Science 74 1326-1335. 
Suwannachot P, Verkleij CB, Weijs WA, van Weeren PR \& Everts ME 1999 Effects of training on the concentration of $\mathrm{Na}^{+}, \mathrm{K}^{+}-$ ATPase in foal muscle. Equine Veterinary Journal Supplement $\mathbf{3 1}$ 101-105

Swann AC 1984 Caloric intake and $\mathrm{Na}^{+}, \mathrm{K}^{+}$-ATPase: differential regulation by $\alpha_{1}$ - and $\beta$-noradrenergic receptors. American Journal of Physiology 247 R449-R455.

Sweadner KJ 1989 Isozymes of the $\mathrm{Na}^{+}, \mathrm{K}^{+}$-ATPase. Biochimica et Biophysica Acta 988 185-220.

Valette JP, Barrey E, Jouglin M, Courouce A, Auvinet B \& Flaux B 1999 Standardisation of muscular biopsy of gluteus medius in French trotters. Equine Veterinary Journal Supplement 30 342-344.
Wartofsky L \& Burman KD 1982 Alteration in thyroid in patients with systemic illness: the 'euthyroid sick syndrome'. Endocrinology Reviews 3 164-217.

Yambayamba ESK, Price MA \& Foxcroft GR 1996 Hormonal status, metabolic changes, and resting metabolic rate in beef heifers undergoing compensatory growth. Journal of Animal Science $\mathbf{7 4}$ $57-69$.

Received 5 May 2000

Revised manuscript received 24 May 2000 Accepted 22 June 2000 